\title{
The Long Arm of an Unsupportive Work-Family Culture in Work Organizations: Crossover to the Partner's Work-Family Balance Satisfaction in Dual-Earner Couples
}

\author{
Janine Bernhardt ${ }^{1}$ (D) Mareike Bünning ${ }^{2}$ (D)
}

Received: 19 August 2020 / Accepted: 3 January 2021 / Published online: 23 March 2021

(C) The Author(s) 2021

\begin{abstract}
This study analyzes how an unsupportive organizational work-family culture experienced by one employed parent at work can cross over to their partner and reduce the latter's satisfaction with work-family balance (WFBS). Workplace cultures that are structured around the "ideal worker" norm have enormous and often detrimental impacts on parents' abilities to manage work and family roles. Drawing on crossover theory, we argue that these kinds of unsupportive work-family cultures have adverse consequences, not only for working parents but also for their partners. We hypothesize that if one partner experiences an unsupportive work-family culture, they can provide less instrumental and emotional support to the other partner, which reduces the other partner's WFBS. We use a unique dataset of 556 dual-earner couples with young children surveyed in Germany in 2015 and perform multivariate regression analysis and structural equation modelling. We find robust evidence that mothers were less satisfied with work-family balance if fathers reported an unsupportive work-family culture in their organization. There was only weak evidence, however, for crossover between an unsupportive work-family culture at the mother's workplace and the father's WFBS. Mediation analysis suggests that these associations were transmitted in part through reduced emotional support, whereas instrumental support did not appear to play a role. The findings lend support to the argument that an unsupportive workfamily culture in one parent's workplace reduces the emotional support they provide to their partner, which reduces the partner's WFBS.
\end{abstract}

Keywords Work-family balance satisfaction · Organizational work-family culture $\cdot$ Ideal worker norm · Crossover · Social support

Janine Bernhardt

bernhardt@dji.de

Extended author information available on the last page of the article 


\section{Introduction}

Work-family balance is becoming an increasingly important component of quality of life since throughout much of the industrialized world, most parents today are dualearner couples (OECD 2019). These couples juggle work demands and family responsibilities on a daily basis. As this family model has become more prevalent, researchers have become increasingly interested in how satisfied employed parents are with their work-family balance and in the factors that increase or reduce their satisfaction (Voydanoff 2005a; Valcour 2007; Beham and Drobnič 2010; Abendroth and den Dulk 2011; Goñi-Legaz and Ollo-López 2016; Vieira et al. 2018; Moazami-Goodarzi et al. 2019; Junker and van Dick 2020).

As previous research has shown, work-family balance improves the well-being of the employed parent (Szücs et al. 2011; Barnett et al. 2019; Nomaguchi and Milkie 2020; Schnettler et al. 2020), their partner (Demerouti et al. 2005; Matias et al. 2017; Vieira et al. 2018; Schnettler et al. 2020), and their children (Milkie et al. 2010). Moreover, employers also benefit. Employees who perceive that work interferes with their family lives show less organizational commitment and lower work performance than those who are able to balance work and family satisfactorily. They also have higher rates of absenteeism and higher turnover intentions (Moazami-Goodarzi et al. 2019).

Yet organizations vary in the degree to which they have adapted to the new realities of the dual-earner family. Many still have a work culture that is structured around the male breadwinner / female caregiver model and assumes an "ideal worker" who is unencumbered by outside demands and available to the employer at all times (Acker 1990; Williams 2000; Las Heras Maestro et al. 2020; Nomaguchi and Milkie 2020). This unsupportive work-family culture makes work-family balance difficult for two reasons: First, it imposes time demands that limit the time available for the family. Second, it imposes strain-based demands that exhaust parents' psychological capacities. Both types of demands deplete parents' resources, limit their capacity to fulfill their role as parents and partners, and therefore are likely to compromise their workfamily balance satisfaction (Greenhaus and Beutell 1985; Crouter et al. 2001).

Existing literature on work-family cultures has concentrated largely on the impacts of supportive versus unsupportive workplace cultures on employed parents (Allen 2001; Voydanoff 2005b; Allard et al. 2011; Clark et al. 2017; Abendroth and Reimann 2018; van der Lippe and Lippényi 2020). Yet family members' lives are intertwined (Elder 1994), and the entire family's well-being is likely to be affected when unfavorable workplace conditions deplete one parent's resources (Moen 2003; Cha 2010; Craig and Brown 2017). This is being addressed by a growing literature on crossover in strain and well-being between individuals and their partners (Westman 2001; Bakker et al. 2008; Bakker et al. 2009; Matias et al. 2017; Brough et al. 2018; Cozzolino et al. 2018).

In this paper, we therefore take a couple perspective on work-family balance satisfaction and assess both parents' satisfaction with their household's work-family balance rather than each parent's satisfaction with his or her individual work-family balance. Our contribution to the literature is threefold. First, we integrate the literatures on work-family balance satisfaction (Voydanoff 2005a; Valcour 2007; Beham and Drobnič 2010; Vieira et al. 2018; Junker and van Dick 2020), crossover (Westman 2001; Bakker et al. 2009; Brough et al. 2018), and the impacts of unsupportive workfamily cultures on employed parents (Allen 2001; Voydanoff 2005b; Allard et al. 2011; 
Clark et al. 2017; Abendroth and Reimann 2018; Cozzolino et al. 2018; Las Heras Maestro et al. 2020; van der Lippe and Lippényi 2020) into one theoretical framework. Second, using couple data for Germany from 2015, we test this framework by analyzing whether an unsupportive work-family culture in one parent's workplace is related to lower satisfaction with work-family balance in their partner and whether this crossover process differs by gender. Third, we provide novel insights into the mechanisms responsible for crossover by theorizing and analyzing the mediating role of instrumental and emotional social support.

Using data for Germany allows a conservative test of the role of an unsupportive work-family culture in couples' work-family balance satisfaction. In Germany, the "one-and-a-half earner model" (Lewis 2001) is the predominant employment pattern among couples with children, and long work weeks are less common there than elsewhere in Europe and in the United States (OECD 2017). Given that long working hours are less prevalent in German workplaces, and that many mothers resolve tensions between work and family by reducing their hours to part-time, we expect that adverse consequences of an unsupportive work-family culture are less likely to cross over to partners in Germany than in other countries.

\section{Work-Family Balance Satisfaction and the Impact of an Unsupportive Work-Family Culture}

\section{Work-Family Balance Satisfaction}

This study focuses on work-family balance satisfaction (WFBS), which is an important facet of work-nonwork balance (Abendroth and den Dulk 2011; Greenhaus and Allen 2011; Casper et al. 2018). Despite notable developments over the past two decades, theoretical and empirical work on the definition and measurement of the concept of work-nonwork balance is still evolving and contested. We understand WFBS as a global, subjective, affective and relational assessment of work and family role fit among parenting couples that refers to the interaction between the two domains without reference to cross-domain processes or direction (see Wayne et al. 2017 for an overview). Our definition of WFBS thus builds on lines of research that have conceptualized balance as an overall, integrative assessment of work and nonwork role compatibility (Voydanoff 2005a; Grzywacz and Carlson 2007; Valcour 2007; Greenhaus and Allen 2011; Wayne et al. 2017; Casper et al. 2018). This approach differs from other lines of research that study balance as the sum of positive and negative spillover assessments between work and nonwork life (Greenhaus and Beutell 1985; Frone 2003; Yucel 2020) or examine satisfaction with work and family as separate aspects (Clark 2001; Carlson et al. 2009; Vieira et al. 2018). ${ }^{1}$

\footnotetext{
${ }^{1}$ WFBS is hence distinct from other widely used concepts such as work-family conflict and work-family enrichment. Work-family conflict, defined as the extent to which participation in one domain is made more difficult by participation in the other (Greenhaus and Beutell 1985), and work-family enrichment, defined as the extent to which participation in one domain is made easier by the experiences, skills, and opportunities gained or developed in the other domain (Greenhaus and Powell 2006), are bidirectional assessments of how work and family influence each other (Casper et al. 2018). Empirical findings suggest that balance satisfaction is partly determined by the levels of work-family conflict and enrichment (Beham and Drobnič 2010).
} 
Within the global-construct approaches of balance, most conceptions today agree that assessments of work-family balance should be framed in subjective terms. ${ }^{2}$ As subjective evaluations of balance require internal reflection and judgment, they have also been described as psychological constructs of balance (Valcour 2007). This psychological construct has two distinct components, a cognitive and an affective one (Wayne et al. 2017; Casper et al. 2018). In our definition, WFBS is an affective appraisal that entails a positive feeling or emotional state (Valcour 2007) that arises when parents think about how they and their partner manage work and family tasks. The theoretical crossover framework proposed below suggests that parents' affective appraisals of WFBS are preceded by cognitive evaluations of how both partners support each other in meeting work-family demands.

In addition, we follow scholars who have argued that balance assessments have a relational dimension (Grzywacz and Carlson 2007; Wayne et al. 2017). Grzywacz and Carlson (2007, p. 466) define work-family balance "as accomplishment of role-related expectations that are negotiated and shared between an individual and his or her role-related partners in the work and family domains". This argument aligns with our reasoning for the crossover of parents' working conditions to their partner's WFBS and the role of social support in this process (see below). We expect that in couples, both partners' satisfaction with work-family balance will be interrelated because they share expectations about work and family roles and take into account their own and their partner's involvement in work and family when making their judgements.

WFBS has been conceptualized within a demands-and-resources framework. According to Voydanoff's definition, "[d]emands are structural or psychological claims associated with role requirements, expectations, and norms to which individuals must respond or adapt by exerting physical or mental effort. Resources are structural or psychological assets that may be used to facilitate performance, reduce demands, or generate additional resources" (Voydanoff 2004, pp. 398-399). The level of WFBS depends on the extent to which work and family resources are sufficient to meet work and family demands (Valcour 2007).

\section{The Role of an Unsupportive Work-Family Culture for Work-Family Balance Satisfaction}

There is ample evidence that workplace culture is related to employees' ability to balance work commitments with family responsibilities (Lewis 1997; Bond 2004; Mennino et al. 2005; Beham and Drobnič 2010; Abendroth and Reimann 2018; Las Heras Maestro et al. 2020; van der Lippe and Lippényi 2020). Workplace culture has been defined as "the prevailing but often unarticulated norms, values and assumptions that underpin working practices" (den Dulk et al. 2011, p. 27; see also Mennino et al. 2005 , for a similar definition).

\footnotetext{
${ }^{2}$ Early balance approaches equated balance with equality, such as an equal level of contentment with work and family roles (Greenhaus et al. 2003). Subjective balance approaches criticized this objectifying definition by arguing that feelings of balance can vary individually depending on, for instance, the centrality of family and work in one's life (Greenhaus and Allen 2011).
} 
A supportive workplace culture can be a resource for employees, whereas an unsupportive workplace culture imposes work demands that threaten work-family balance (Voydanoff 2005b). A supportive work-family culture, that is, one that encourages the use of work-family policies and guarantees that employees will not suffer career penalties for making use of these policies, is related to lower levels of workfamily conflict and increased levels of satisfaction in working parents (Mennino et al. 2005; Clark et al. 2017; Abendroth and Reimann 2018; van der Lippe and Lippényi 2020).

Yet prevailing workplace norms often create powerful barriers to workfamily balance. For decades, organizational cultures have been structured around an "ideal worker" norm (Amstad et al. 2011) that expects employees to be unencumbered by outside demands and always available when the employer needs them. This includes a willingness to work long hours, put in extensive "face time", be on call, and respond to unexpected work demands at short notice (Acker 1990; Williams 2000; Williams et al. 2013; Lott and Klenner 2018).

As Acker (1990) has argued, the "ideal worker" norm is shaped around assumptions of a male breadwinner whose female partner stays home taking care of the children and the household. This assumption does not fit the reality of dual-earner families. But employees who reduce their working hours or who are unable to work overtime or respond flexibly to their employer's needs risk having their skills and their professional commitment, motivation, and willingness to work questioned (Epstein et al. 1999; Blair-Loy 2003; Vinkenburg et al. 2012). The consequences of this so-called "flexibility stigma" (Williams et al. 2013) include being assigned less challenging tasks, receiving lower evaluations and wages, and consequently having reduced career prospects (Leslie et al. 2012; Williams et al. 2013; Fuller and Hirsh 2019).

Hence, in unsupportive work-family cultures, mothers and fathers feel pressured to comply with the "ideal worker" norm at the expense of workfamily balance. This applies to both genders, though with some differences: Motherhood is often regarded as incompatible with the "ideal worker" norm because of prevalent cultural norms of extensive mothering (Hays 1996; Lareau 2003; Grunow et al. 2018), which makes it more acceptable for mothers to reduce their working hours. Nevertheless, when highly qualified mothers switch to part-time work, their workloads are often not reduced and they are expected to increase their pace of work to deliver performance similar to that of full-time workers (Lott and Klenner 2018). In the case of fathers, studies indicate that men who want to be actively involved in their children's lives often keep their family responsibilities hidden at work (Sallee 2012; Williams et al. 2013). Accordingly, fathers who perceive their organization to have an unsupportive work-family culture work longer hours than fathers who do not (Bernhardt and Bünning 2020). This indicates that unsupportive workplace cultures impinge on family life in two ways: First, availability demands limit the time individuals can dedicate to responsibilities outside work. Second, high workloads and performance expectations can produce strain that drains people's emotional capacities for non-work responsibilities (Greenhaus and Beutell 1985; Voydanoff 2005b). 


\section{Crossover Effects of Unsupportive Work-Family Cultures in Couples and the Role of Social Support}

\section{Crossover Effects of Workplace Conditions in Couples}

An unsupportive work-family culture may not only compromise the WFBS of the individual employee, but also that of his or her partner as the demands imposed on one partner constrain and bind the resources of the entire family (Voydanoff 2005a). An abundant literature on crossover effects shows that family members' lives are intertwined and that the strain or well-being of one partner crosses over to the other (Westman 2001; Bakker et al. 2008; Bakker et al. 2009; Matias et al. 2017; Brough et al. 2018; Cozzolino et al. 2018; Booth-LeDoux et al. 2020).

Westman and Etzion (2005) defined crossover as "the process that occurs when a stressor or psychological strain experienced by one person affects the level of stress or strain of another person in the same social environment" (p. 1940). Hence, in couple relationships, the stress experienced by one partner at work may also lead to stress in the other partner at home. Positive experiences and feelings may be transmitted to the partner in a similar way.

Job demands and resources are main antecedents in the crossover process (Bakker et al. 2009; Matias et al. 2017). Even though the crossover literature has developed independently of the literature on WFBS to date, both can be easily integrated into a larger theoretical framework because both WFBS and the crossover process have been conceptualized within a relational demands-and-resources framework.

\section{Social Support as a Mechanism}

Research has also attempted to identify the mechanisms explaining the crossover process. One of these mechanisms is social support. Whereas research demonstrates that social support is beneficial for the recipient (Carlson and Perrewé 1999; Michel et al. 2010; Abendroth and den Dulk 2011; Junker and van Dick 2020), Westman (2001) pointed out that the effects on the support provider also need to be considered to understand the crossover process.

If one partner in a couple experiences stress and strain at work, this may affect the exchange of social support between the partners in two ways. First, experiences of stress and strain reduce the amount of support an individual can provide to their partner. Second, such experiences increase the individual's need for support from their partner. Both processes deplete the partner's resources and may reduce the partner's well-being and WFBS.

Studies on social support typically distinguish between instrumental and emotional social support (see, e.g., Kumar et al. 2019). Emotional support involves people making themselves available to listen, to care, to sympathize, to provide reassurance, and to make one feel valued, loved, and cared for. Instrumental support involves people providing concrete assistance, such as help with household chores (House 1981; Abendroth and den Dulk 2011).

Both types of social support may matter for the crossover of work-related demands imposed on one partner into reduced WFBS on the part of the other partner. Regarding 
instrumental support, one parent's job demands may make it difficult or impossible for that parent to perform parenting tasks at home. The second parent has to step in and take on additional responsibilities at home, which will reduce his or her WFBS. Regarding emotional social support, stress and strain experienced by one partner may result in a less empathetic interaction style, resulting in higher levels of conflict in couples and thus reducing the partner's well-being and WFBS (Abendroth and den Dulk 2011).

Some evidence in this direction is provided by Bakker et al. (2008) who show that higher workplace demands by one partner were related to increased experiences of work-family conflict experienced by this person, and these were associated with higher levels of home demands (home overload and emotional demands) for the second partner. These higher home demands in turn were related to higher levels of familywork conflict by the second partner.

The argument has also been taken up by several other studies that did not test this link directly. For instance, ten Brummelhuis et al. (2010) wrote: "We acknowledge that the man's work demands may increase the woman's family load (and vice versa) as heavier work demands limit how much time and energy the man has to participate in family tasks" (pp. 327-328). In a similar vein, Demerouti et al. (2005) speculated that the reason exhaustion crossed over from women to their partners in their study may be that men had to perform more domestic tasks when their partner was exhausted.

\section{Gender Differences in the Crossover Process}

Previous research has also been interested in whether there are gender differences in the crossover process. The results of this research have been ambiguous to date. Most researchers who considered gender differences have argued that crossover from men to women should be more pronounced than vice versa because women presumably are more empathetic and-important to our studymore likely to provide social support. Furthermore, men may react in a more hostile manner when stressed, which can also be understood as a withdrawal of emotional social support (Westman 2001; ten Brummelhuis et al. 2010). Another argument in this direction is that given normative gender roles, successfully managing family demands is more salient to women's identity and perception of role performance. Hence, if family life is compromised because of a strong "ideal worker" norm at either partner's workplace, this may be more consequential for women's WFBS than for men's (Valcour 2007). By contrast, some scholars have found empirical support for stronger crossover from mothers to fathers and have argued that men should be more susceptible to the working conditions of their partner as their parental role is less scripted (Matias et al. 2017).

\section{Hypotheses}

The theoretical framework is displayed in Fig. 1. Based on the theoretical arguments and empirical findings laid out above, we expect that in dual-earner couples, if one partner perceives the work-family culture in their organization to be unsupportive, this 
will compromise their own WFBS (solid grey lines) as well as that of their partner (Hypothesis 1, solid black lines).

Furthermore, we expect the relationship between one partner's workplace culture and the other partner's WFBS to be mediated by both instrumental and emotional social support. Regarding instrumental support, we propose that an employed parent who perceives their work-family culture to be unsupportive will spend less time doing housework and childcare (dotted grey lines), whereas their partner will spend more time doing housework and childcare (dotted black lines), which in turn is related to lower WFBS in the partner (Hypothesis 2, dotted black lines in Fig. 1).

Regarding emotional support, we expect that an unsupportive work-family culture will be associated with reduced provision of emotional support by the employed parent (dashed grey lines) and an increased demand for social support by their partner (dashed black lines), which in turn is related to lower WFBS in the partner (Hypothesis 3, dashed black lines in Fig. 1). We do not formulate a hypothesis about gender differences, as the literature reviewed above is ambiguous in this regard.
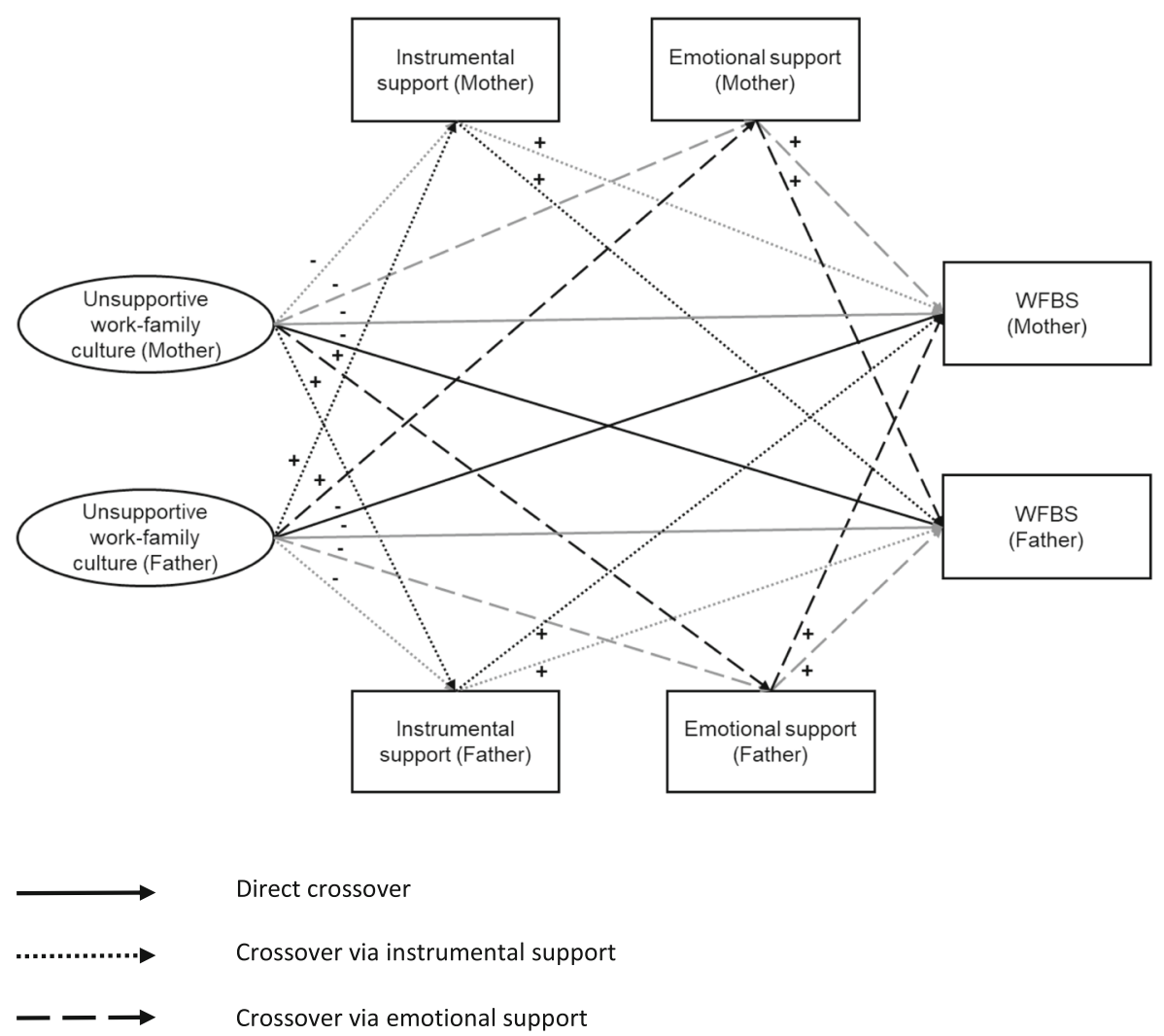

Fig. 1 Theoretical expectations: Mediation model of crossover from an unsupportive work-family culture at mothers' and fathers' workplaces on partners' work-family balance satisfaction (WFBS) 


\section{Data and Methods}

\section{Sample}

This study is based on an individual telephone survey of 878 couples with children in Germany. The data were collected in 2015 as an add-on to the German panel study survey AID:A ("Growing up in Germany"). The original AID:A study drew a sample from population registration data in 300 municipalities in 2009 and realized interviews with 25,000 persons born between 1954 and 2009 or their legal guardians. ${ }^{3}$ The sample for the add-on study was drawn from the second wave, surveyed between 2013 and 2015 (AID:A II). The aim of this survey was to increase our knowledge on the influence of workplace conditions on work-family balance and parental division of labor. To this end, both partners in cohabiting couples were asked about the structural and cultural characteristics of their workplaces.

The target population consisted of different-sex couples with a) at least one partner in dependent employment and b) at least one child under 13 years of age living in their shared household. Young children in early and middle childhood impose higher immediate care demands on parents than older children - they require intensive physical care, supervision, and stimulation. Work-family research from different disciplinary angles indicates that aligning job demands and childcare responsibilities is highly difficult for parents of young children, particularly mothers (for reviews, see Nomaguchi and Milkie 2020; Perry-Jenkins and Gerstel 2020). Thus, if instrumental and emotional partner support are relevant mediators in the crossover from the unsupportive work-family culture in one partner's workplace to the other partner's WFBS, we should be most likely to observe these relationships in this group.

For the purpose of our study, we restricted the sample to dual-earner couples in dependent employment $(N=556)$. The sample was stratified by employment constellations. In order to study issues such as part-time work by fathers, we opted to oversample rare employment constellations (both parents working part-time, both full-time, woman full-time and man part-time or not employed) relative to their actual occurrence in Germany. Within these individual constellations, a random selection was performed. By using weighting factors based on the 2013 German Microcensus, we were able to obtain a sample that is representative with regard to the following characteristics: the couples' employment constellations, marital status, number and ages of children in the household, state of residence, age, and level of education.

\section{Measures}

The measures used in this study are based on mothers' and fathers' subjective assessments of their level of WFBS, their provision of instrumental and emotional support, and the work-family cultures in their organizations. By using subjective measures of organizational work-family culture, we build on theoretical (e.g., Kossek et al. 1999) and empirical (e.g., Allen 2001; Booth and Matthews 2012) literature suggesting that perceived social expectations at work have a strong impact on work-family balance and well-being that is independent of the existence of formal work-family policies. Table 1

\footnotetext{
${ }^{3}$ www.dji.de/aida-overview
} 
provides an overview of the variables used, including exact item wording, and descriptive statistics.

Work-Family Balance Satisfaction (WFBS) The dependent variable in this study is represented by the following single-item measure: "How satisfied are you with the work-family balance in your household?" The response scale ranges from 0 (not at all satisfied) to 10 (fully satisfied). The measure denotes a global, affective, and relational appraisal of the overall fit of work and family life (for further details, see above). As suggested by a comprehensive conceptual review (Casper et al. 2018), our operationalization is unidimensional, capturing only one of multiple facets of balance. The measure is similar to the fit appraisal question in the five-item scale developed by Valcour (2007), which additionally includes the dimensions of involvement and performance balance. However, our measure differs from this and other previous studies in one important respect: it focuses on the household context. Existing measures (see Casper et al. 2018) restrict work-family balance to individuals' assessments of their personal allocation of resources and have been criticized for neglecting the interrelatedness of WFBS between role partners (Grzywacz and Carlson 2007). By using this extended version of Valcour's item on satisfaction with work-family fit, we seek to overcome this limitation and account for the fact that in dual-earner families, one partner's working conditions can also enhance or limit their partner's opportunities to balance work and family roles and thereby compromise the overall balance in the household.

Unsupportive Work-Family Culture Perceptions of an unsupportive work-family culture in the workplace are represented by a scale consisting of four items adapted from Booth and Matthews (2012), which is a validated, shortened version of the highly recognized measure developed by Allen (2001). Several recent studies on unsupportive work-family culture have used similar items (e.g., van der Lippe and Lippényi 2020; Abendroth and Reimann 2018), though no particular scale has gained dominance in the literature yet. Again, responses were measured on a 10-point scale, ranging from 0 (do not agree at all) to 10 (agree completely). The fit statistics (using full information maximum likelihood estimation and bootstrapping with 2000 replications) meet the standard requirements to accept the scale for both mothers $\left(\chi^{2}(2)=4.82, p=.09\right.$; $\mathrm{RMSEA}=.05 ; \mathrm{CFI}=.99$; TLI = .99; Cronbach's Alpha: .82) and fathers $\left(\chi^{2}(2)=0.88, p=.64\right.$; RMSEA $=.00 ;$ CFI $=1.00 ;$ TLI $=1.00 ;$ Cronbach's Alpha: .81).

Instrumental Support We used a continuous variable consisting of the number of hours per normal workday spent by each parent on unpaid work, consisting of childcare and housework.

Emotional Support In close relationships, social support (and the lack thereof) includes positive aspects, such as appreciation, as well as negative aspects, such as conflicts (Abbey et al. 1985). The data in our study provide information only on the negative side, i.e., relationship conflicts. However, early research suggested that conflicts tend to represent the opposite end of a continuum of social support in close relationships (Abbey et al. 1985), and recent studies have followed this approach by using relationship conflicts as an indicator of reduced mutual emotional support between partners 
(Abendroth and den Dulk 2011). We therefore measured (the lack of) emotional support with the following statement: "I often have conflicts with my partner because of my workload". Again, the response scale ranged from 0 (do not agree at all) to 10 (agree completely).

\section{Analytic Strategy and Methods}

Using structural equation modelling (SEM), we proceeded in two steps. First, we ran a set of regression analyses, in which we tested whether the hypothesized direct crossover relationships between one partner's unsupportive work-family culture and the other partner's WFBS was robust to the inclusion or exclusion of control variables. Second, we conducted mediation analyses using a dyadic framework to investigate and compare the hypothesized mechanisms between mothers and fathers. We used this two-step procedure due to the complexity of the dyadic mediation setup, which considerably limits the number of control variables that can be included.

In the first step, we estimated four models, two for each parent, regressing WFBS on both partners' ratings of an unsupportive work-family culture in their individual workplaces. All models controlled for couples' employment arrangements as the stratification characteristic of the sample (Cameron and Trivedi 2005). The full models also controlled for potentially confounding characteristics of both parents, their workplaces, and their household context (see Table 1). As workplace characteristics, we included the sector and establishment size of each parent's workplace. As individual characteristics, we considered each parent's age, education, and occupational position as well as one attitudinal indicator of gender roles and one of stress resistance (Rammstedt and John 2007). At the household level, we controlled for the region of residence (eastern vs. western Germany), marital status (married vs. cohabitating), as well as the number and age of their children (Lott and Klenner 2018; Perry-Jenkins and Gerstel 2020).

In the second step, we used a dyadic mediation framework, which simultaneously included both partners' perceptions of an unsupportive work-family culture, the two mediators - instrumental and emotional support - and both partners' WFBS within a single model (see also Fig. 1 for all paths included in the analysis). In addition, we controlled for the stratification of the sample by including couples' employment arrangements. This method allowed us to take account of potential interdependencies between the two partners by analyzing crossover effects of both partners simultaneously.

All model calculations were based on full information maximum likelihood estimation (FIML) and bootstrapping. Eight percent of the 556 couples in our data had a missing value on at least one variable. However, the distribution of the cumulated missing values across observations showed no systematic patterns. FIML allowed us to use all available information given by the respondents in the data (no listwise deletion). A comparison of models using FIML, OLS with listwise deletion and multiple imputation for the first step of our analysis yielded very similar results (available upon request). Bootstrapping is a nonparametric approach to statistical inference that is useful when samples are small and when distributional assumptions are not known or may not be met. Model parameters are estimated strictly from the sample (Preacher and 
Table 1 Overview of Variables and Descriptive Statistics

\begin{tabular}{|c|c|c|c|c|c|}
\hline \multirow[t]{2}{*}{ Variable } & \multirow[t]{2}{*}{ Description } & \multicolumn{2}{|l|}{ Mothers } & \multicolumn{2}{|l|}{ Fathers } \\
\hline & & $\begin{array}{l}\text { Mean } \\
(\mathrm{SD}) / \text { Share }\end{array}$ & $\mathrm{N}$ & $\begin{array}{l}\text { Mean } \\
(\mathrm{SD}) / \text { Share }\end{array}$ & $\mathrm{N}$ \\
\hline \multicolumn{6}{|l|}{ Individual level } \\
\hline $\begin{array}{l}\text { Work-family balance } \\
\text { satisfaction }\end{array}$ & $\begin{array}{l}\text { "How satisfied are you with the } \\
\text { work-family balance in your } \\
\text { household?" } \\
0=\text { not at all satisfied, } 10=\text { fully satisfied }\end{array}$ & $7.06(1.78)$ & 556 & $7.12(1.63)$ & 556 \\
\hline \multirow[t]{4}{*}{$\begin{array}{l}\text { Unsupportive work-family } \\
\text { culture }\end{array}$} & $\begin{array}{l}\text { 1. "Employees who are highly } \\
\text { committed to their personal lives } \\
\text { cannot be highly committed to their } \\
\text { work." }\end{array}$ & $3.88(2.83)$ & 550 & $3.57(2.77)$ & 548 \\
\hline & $\begin{array}{l}\text { 2. "It is assumed that the most } \\
\text { productive employees are those } \\
\text { who put their work before their } \\
\text { family life." }\end{array}$ & $4.77(3.42)$ & 553 & $4.71(3.32)$ & 552 \\
\hline & $\begin{array}{l}\text { 3. "The way to get ahead is to keep } \\
\text { non-work matters out of the work- } \\
\text { place." }\end{array}$ & $4.52(3.35)$ & 551 & $4.41(3.18)$ & 551 \\
\hline & $\begin{array}{l}\text { 4. "Attending to personal needs, such } \\
\text { as taking time off for sick children } \\
\text { is frowned upon." } \\
0=\text { do not agree at all, } 10=\text { agree } \\
\text { completely }\end{array}$ & $3.74(3.17)$ & 554 & $3.16(2.89)$ & 554 \\
\hline Instrumental support & $\begin{array}{l}\text { Hours spent on childcare and } \\
\text { housework on a normal workday }\end{array}$ & $6.96(3.13)$ & 550 & $4.02(2.39)$ & 549 \\
\hline Emotional support & $\begin{array}{l}\text { "I often have conflicts with my partner } \\
\text { because of my workload." } \\
0=\text { do not agree at all, } 10=\text { agree } \\
\text { completely }\end{array}$ & $2.81(2.48)$ & 556 & $3.05(2.60)$ & 556 \\
\hline \multirow[t]{5}{*}{ Sector } & $\begin{array}{l}\text { Administration/healthcare/social } \\
\text { services }\end{array}$ & .59 & 556 & .35 & 556 \\
\hline & Production & .10 & & .24 & \\
\hline & Retail/hospitality & .08 & & .08 & \\
\hline & Scientific services & .08 & & .10 & \\
\hline & Other sectors & .15 & & .23 & \\
\hline \multirow[t]{3}{*}{ Establishment size } & Small: Up to 10 employees & .14 & 555 & .08 & 551 \\
\hline & Medium: 11-249 employees & .51 & & .48 & \\
\hline & Large: 250 and more employees & .35 & & .43 & \\
\hline \multirow[t]{3}{*}{ Occupational position } & Blue collar & .04 & 553 & .09 & 556 \\
\hline & White collar & .77 & & .77 & \\
\hline & Civil servant & .19 & & .15 & \\
\hline Management position & $1=$ yes, $0=$ no & .26 & 556 & .48 & 556 \\
\hline Education & $\begin{array}{l}1=\text { tertiary degree, } 0=\text { vocational degree } \\
\quad \text { or lower }\end{array}$ & .61 & 556 & .58 & 556 \\
\hline Age & In years & $42.02(5.38)$ & 555 & $44.54(5.84)$ & 556 \\
\hline
\end{tabular}


Table 1 (continued)

\begin{tabular}{|c|c|c|c|c|c|}
\hline \multirow[t]{2}{*}{ Variable } & \multirow[t]{2}{*}{ Description } & \multicolumn{2}{|l|}{ Mothers } & \multicolumn{2}{|l|}{ Fathers } \\
\hline & & $\begin{array}{l}\text { Mean } \\
(\mathrm{SD}) / \text { Share }\end{array}$ & $\mathrm{N}$ & $\begin{array}{l}\text { Mean } \\
(\mathrm{SD}) / \text { Share }\end{array}$ & $\mathrm{N}$ \\
\hline $\begin{array}{l}\text { Egalitarian gender role } \\
\text { attitudes }\end{array}$ & $\begin{array}{l}\text { "Men are better suited to some jobs, } \\
\text { women to others." } \\
\text { 1=do not agree/ do not at all agree, } 0= \\
\text { agree completely/ tend to agree }\end{array}$ & .45 & 556 & .35 & 553 \\
\hline Handles stress well & $\begin{array}{l}\text { "I see myself as someone who is } \\
\text { relaxed, handles stress well." } \\
0=\text { do not agree at all, } 10=\text { agree } \\
\text { completely }\end{array}$ & $6.27(2.08)$ & 556 & $6.62(2.00)$ & 555 \\
\hline Couple level & & Share & & $\mathrm{N}$ & \\
\hline Region & $\begin{array}{c}1=\text { couple lives in eastern Germany, } 0= \\
\text { couple lives in western Germany }\end{array}$ & .23 & & 556 & \\
\hline Marital status & $1=$ married, $0=$ not married & .92 & & 556 & \\
\hline Age of youngest child & $\begin{array}{l}1=\text { under } 3 \text { years, } 0=\text { aged } 3 \text { years or } \\
\text { more }\end{array}$ & .14 & & 556 & \\
\hline Number of children & $\begin{array}{l}1=3 \text { or more children, } 0=1 \text { or } 2 \\
\text { children }\end{array}$ & .23 & & 556 & \\
\hline \multirow[t]{4}{*}{ Employment arrangement } & $\begin{array}{l}\text { Full-time working father, mother } \\
\text { working part-time }\end{array}$ & .56 & & 556 & \\
\hline & Both working full-time & .28 & & & \\
\hline & Both working part-time & .12 & & & \\
\hline & Other & .05 & & & \\
\hline
\end{tabular}

Sample: 556 opposite-sex, dual-earner couples in dependent employment, with at least one child up to 12 years of age in the household, standard deviation (SD) in parentheses, unweighted data.

Hayes 2008). Following previous crossover research (ten Brummelhuis et al. 2010), we used bootstrapping with 2000 replications to calculate the direct effects, indirect effects, standard errors, and bias-corrected confidence intervals for the indirect crossover effects.

In a series of alternative specifications, discussed at the end of the results section, we tested for the robustness of our results and further explored gender differences in the crossover process. All models were estimated with Stata 15.1.

\section{Results}

In the first step, we describe the results of the multivariate regression analyses, in which we tested direct crossover relationships between mothers' and fathers' perceptions of an unsupportive work-family culture in their workplace and their partners' work-family balance satisfaction (WFBS) (Hypothesis 1). Table 2 shows four models, two for mothers and two for fathers. All models regressed WFBS on individuals' and partners' experiences of an unsupportive work-family culture in the workplace. Models 1 and 3 only controlled for couples' employment arrangements. Models 2 and 4 include all 
Table 2 Regression Models of Work-Family Balance Satisfaction: Crossover of Partners' Experience of an Unsupportive Work-Family Culture in Their Workplaces

Work-Family Balance Satisfaction

Mothers $\quad$ Fathers

(1)

(2)

(3)

(4)

\begin{tabular}{|c|c|c|c|c|c|c|c|c|}
\hline $\begin{array}{l}\text { Unsupportive work-family culture } \\
\text { at own workplace }\end{array}$ & $-0.21^{* * *}$ & $(0.03)$ & $-0.21^{* * *}$ & $(0.03)$ & $-0.16^{* * *}$ & $(0.03)$ & $-0.16^{* * *}$ & $(0.03)$ \\
\hline $\begin{array}{l}\text { Unsupportive work-family culture } \\
\text { at partner's workplace }\end{array}$ & $-0.07^{*}$ & $(0.03)$ & $-0.08^{*}$ & $(0.03)$ & -0.03 & $(0.03)$ & -0.05 & $(0.03)$ \\
\hline Employment arrangement & Yes & & Yes & & Yes & & Yes & \\
\hline Controls & No & & Yes & & No & & Yes & \\
\hline Observations & 556 & & 556 & & 556 & & 556 & \\
\hline
\end{tabular}

Note: Unstandardized coefficients, bootstrap standard errors in parentheses (2000 replications); controls: both partners' sector, establishment size, occupational position, management position, education, age, gender role attitudes, stress resistance, region, marital status, age of youngest child, number of children. Coefficients for control variables are shown in the Appendix in Table 4.

$* p<0.05, * * p<0.01, * * * p<0.001$; unweighted data; sample: dual-earner couples

control variables at the individual and couple level (see Table 4 in the Appendix). The results indicate that both parents were significantly less satisfied with work-family balance when they perceived the work-family culture in their own workplace as unsupportive, with larger effect sizes for mothers than for fathers.

Moreover, Models 1 and 2 provide robust evidence that mothers were more dissatisfied if their partner reported an unsupportive work-family culture in his workplace. Each unit increase in the 10-point scale of fathers' perceptions of an unsupportive work-family culture was associated with an average decrease in mothers' WFBS of 0.07 points on the 10-point scale. The effect size of the crossover relationship even increased slightly in Model 2, after controlling for a range of workplace and other characteristics of both mothers and fathers.

Model 3, by contrast, indicates that fathers' WFBS is unrelated to their partner's experience of an unsupportive work-family culture in her workplace. The coefficient for the crossover of mothers' perceptions of an unsupportive work-family culture on fathers' WFBS was small and not statistically significant. In the full Model 4 , the coefficient increased slightly and was marginally significant $(p<.1)$. According to this model, each unit increase in the 10-point scale of mothers' perceptions of an unsupportive work-family culture was associated with an average decrease in fathers' WFBS of 0.05 points in the 10-point scale.

As a test of robustness, we included couples with a father working full-time and a non-employed mother (male breadwinner arrangement) in our sample and analyzed whether the crossover from fathers' workplace culture to mothers' WFBS differed depending on the couple's work-care arrangement. On the one hand, mothers in a male breadwinner arrangement may be less affected by an unsupportive work-family culture in their partner's workplace than mothers in a dual-earner arrangement if they actually prefer gendered separate spheres. On the other hand, if mothers have involuntarily 
opted out of the labor force due to an unsupportive work-family culture in their or their partner's workplace (see Cha 2010), they may be particularly dissatisfied with their work-care arrangement. The results of additional regression analyses including interaction models (available upon request) lend support to the second argument, showing that mothers in male breadwinner arrangements were significantly less satisfied with the overall work-family balance in the household. Moreover, the direct crossover associations between an unsupportive work-family culture in fathers' workplaces and mothers' WFBS were nearly identical for both samples and did not differ by the couple's employment arrangement.

In sum, our regression analyses indicated that parents' workplace culture matters for their own WFBS, but robust evidence of crossover emerged only in the effects of fathers' work-family culture on mothers' WFBS. The results thus partially support Hypothesis 1.

In the next step, we tested instrumental and emotional social support as mediators between one parent's perceptions of an unsupportive work-family culture and the other parent's WFBS. Although the direct crossover path between mothers' perceived unsupportive work-family culture and fathers' WFBS was weak, it is still possible that mothers' workplace context indirectly contributed to their partner's satisfaction transmitted by the level of support they provide for their partner (see Hayes 2013). Figure 2 displays all statistically significant paths between the variables of interest. The

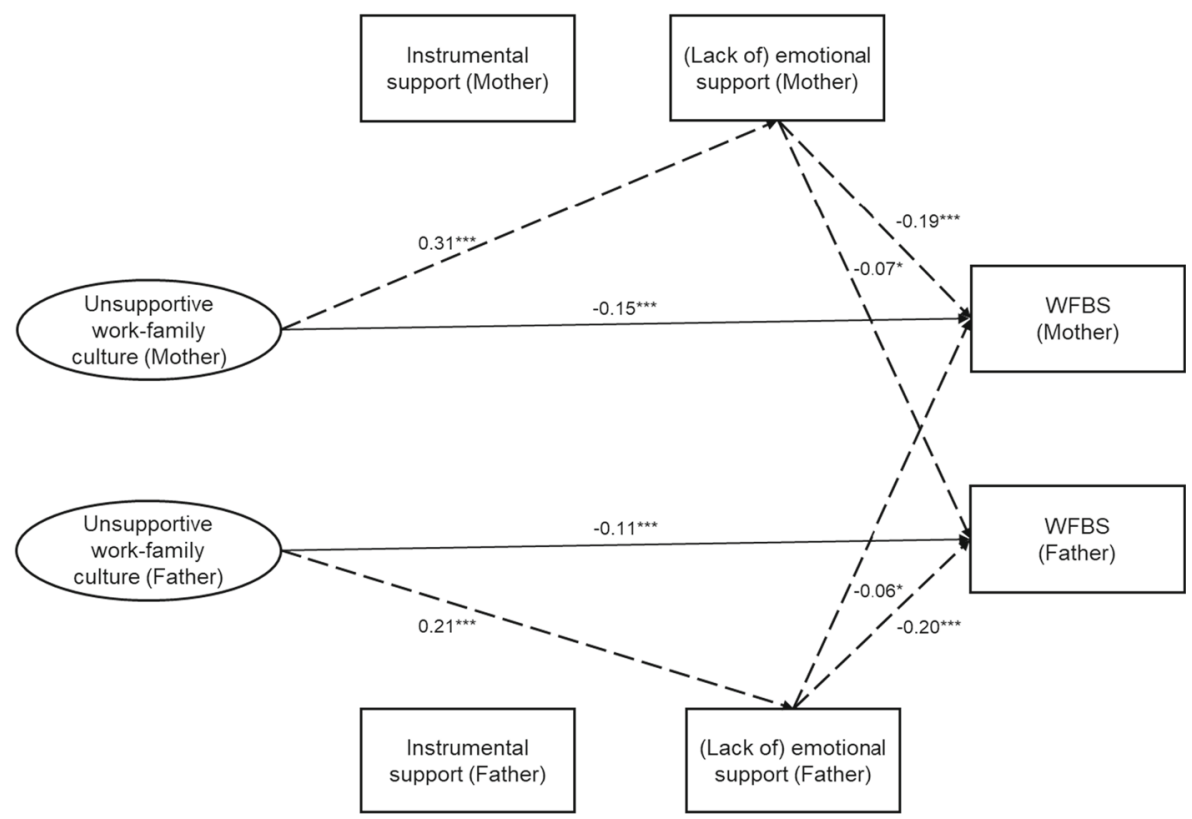

Structural Model, unstandardized coefficients; only statistically significant paths shown, ${ }^{*} p<0.05,{ }^{* *} p<0.01,{ }^{* * *}$ $p<0.001$, based on bootstrap s.e. (2000 replications); $\chi^{2}(77)=87.516, p=0.194$; RMSEA $=0.016$; CFI $=0.995$;

$\mathrm{TLI}=0.991 ; N=556$ couples (556 mothers, 556 fathers); model covariances (not shown in the figure): WFBS (mother), WFBS (father): $0.38^{* * *}$; instrumental support (mother), instrumental support (father): $1.38^{*}$; emotional support (mother), emotional (father): $1.01 * * *$

Fig. 2 Empirical findings: Mediation model of crossover from an unsupportive work-family culture at mothers' and fathers' workplaces on partners' work-family balance satisfaction (WFBS) 
goodness-of-fit indices presented below Fig. 2 indicate a good model fit (see Acock 2013).

Turning to the first mediator, hours spent on unpaid work (childcare and housework), we found no evidence that high work demands by one partner were related to lower WFBS of the other partner because the latter would have to increase his/her contribution to unpaid work. Neither mothers nor fathers spent significantly more time in unpaid work if their partners reported an unsupportive work-family culture at their workplace. Neither mothers nor fathers were less satisfied when their partners spent less time in unpaid work. Although there was a weakly significant, negative association between mothers' experience of an unsupportive work-family culture and their own hours spent in unpaid work ( $p<0.1$, not shown), fathers did not compensate for the mothers' reduced household labor by increasing their own hours of unpaid work. In contrast, the positive covariance between mothers' and fathers' hours spent on childcare and housework indicates a complementary relationship: if one parent did more, so too did the other.

As displayed in Table 3, additional calculations of the indirect crossover effects and bias-corrected confidence intervals using bootstrapping confirmed that both indirect pathways through instrumental social support were not statistically significant. We therefore have to reject Hypothesis 2.

Table 3 Indirect Crossover Effects

\begin{tabular}{|c|c|c|c|c|}
\hline Indirect Effects & $\begin{array}{l}\text { Unstand. } \\
\text { Coefficient }\end{array}$ & $\begin{array}{l}\text { Bootstrap } \\
\text { S.E. }\end{array}$ & \multicolumn{2}{|c|}{$\begin{array}{l}\text { Bias-corrected } \\
95 \% \\
\text { Confidence } \\
\text { Interval }\end{array}$} \\
\hline \multicolumn{5}{|l|}{ Crossover Mother $\rightarrow$ Father } \\
\hline $\begin{array}{l}\text { Unsupportive work-family culture (M) } \rightarrow \text { Instrumental support } \\
(\mathrm{M}) \rightarrow \text { WFBS (F) }\end{array}$ & 0.002 & 0.002 & -0.001 & 0.009 \\
\hline $\begin{array}{l}\text { Unsupportive work-family culture (M) } \rightarrow \text { Emotional support } \\
\qquad(\mathrm{M}) \rightarrow \text { WFBS }(\mathrm{F})\end{array}$ & $-0.022^{*}$ & 0.009 & -0.043 & -0.006 \\
\hline $\begin{array}{l}\text { Unsupportive work-family culture }(\mathrm{M}) \rightarrow \text { Instrumental support } \\
\qquad(\mathrm{F}) \rightarrow \operatorname{WFBS}(\mathrm{F})\end{array}$ & 0.001 & 0.002 & -0.003 & 0.005 \\
\hline $\begin{array}{l}\text { Unsupportive work-family culture }(\mathrm{M}) \rightarrow \text { Emotional support }(\mathrm{F}) \\
\rightarrow \text { WFBS }(\mathrm{F})\end{array}$ & -0.005 & 0.009 & -0.024 & 0.010 \\
\hline \multicolumn{5}{|l|}{ Crossover Father $\rightarrow$ Mother } \\
\hline $\begin{array}{l}\text { Unsupportive work-family culture }(\mathrm{F}) \rightarrow \text { Instrumental support } \\
(\mathrm{F}) \rightarrow \text { WFBS }(\mathrm{M})\end{array}$ & 0.001 & 0.002 & -0.002 & 0.007 \\
\hline $\begin{array}{l}\text { Unsupportive work-family culture }(\mathrm{F}) \rightarrow \text { Emotional support }(\mathrm{F}) \\
\rightarrow \operatorname{WFBS}(\mathrm{M})\end{array}$ & $-0.013^{*}$ & 0.007 & -0.031 & -0.002 \\
\hline $\begin{array}{l}\text { Unsupportive work-family culture }(\mathrm{F}) \rightarrow \text { Instrumental support } \\
\qquad(\mathrm{M}) \rightarrow \text { WFBS }(\mathrm{M})\end{array}$ & -0.000 & 0.002 & -0.004 & 0.003 \\
\hline $\begin{array}{l}\text { Unsupportive work-family culture }(\mathrm{F}) \rightarrow \text { Emotional support }(\mathrm{M}) \\
\rightarrow \text { WFBS }(\mathrm{M})\end{array}$ & -0.010 & 0.008 & -0.025 & 0.004 \\
\hline
\end{tabular}

Note: $M$ mother, $F$ father, WFBS work-family balance satisfaction

$* p<0.05$ 
Turning to the second mediator, work-related conflicts with the partner, Fig. 2 indicates that reduced emotional support mediated the crossover relationships for both parents. In line with our expectations, the more mothers or fathers experienced an unsupportive work-family culture in their workplaces, the more they also experienced work-related conflicts with their partners, who, in turn, felt less satisfied with the overall work-family balance in the household (dashed lines). Both crossover relationships from parents' work-related conflicts to partners' lower WFBS were significant at the 5\% level and of similar size: Fathers' WFBS decreased on average by 0.07 points for each unit increase in the 10-point scale of work-related conflicts reported by mothers; the crossover-related decrease in mothers' WFBS was only slightly lower at 0.06 points.

Additional calculations confirmed that the indirect crossover effects mediated by workrelated partner conflict (Table 3) were statistically significant. Using Stata's nlcom and bootstrapping (see, e.g., UCLA: Statistical Consulting Group n.d.), we found that an increase of one unit in unsupportive work-family culture reported by mothers was associated with a decrease of 0.02 points in fathers' WFBS transmitted by mothers' conflicts with their partner $(-0.02, p<.05)$. Likewise, an increase of one unit in an unsupportive workfamily culture reported by fathers was associated with a decrease of 0.01 points in mothers' WFBS transmitted by fathers' conflicts with their partner $(-0.01, \mathrm{p}<.05)$. Our results thus support Hypothesis 3 on emotional partner support for both parents.

Gender differences in the relevance of emotional support are substantial. Whereas $69 \%$ of the relationship between an unsupportive work-family culture at the mother's workplace and the father's WFBS was transmitted by emotional support, the same was true for only $18 \%$ of the relationship between the father's experience of an unsupportive work-family culture and the mother's WFBS. Nevertheless, after including the mediators into the model, the direct path from fathers' perceptions of an unsupportive work-family culture to mothers' WFBS was smaller in the mediation model than in the main model and only significant at the $10 \%$ level.

In a series of alternative specifications, we tested for the robustness of our results regarding the mediating role of social support. In a first set of models, we included additional control variables. Specifically, we tested for differences related to parents' educational levels and their gender role attitudes because working parents with egalitarian attitudes or high-performance jobs may be particularly dissatisfied with workfamily balance if their partner does not provide their fair share of support due to work demands. As SEM is very limited in its capacity to control for potential confounders, we estimated two separate models, each of which additionally controlled for couples' employment arrangements. Given that mothers often resolve tensions between work and family by switching to part-time employment or dropping out of the labor force (Lewis 2001; OECD 2017), we also conducted separate analyses for the three most common employment arrangements: couples with a father working full-time and a mother working part-time, couples with two full-time working parents, and couples with a father working full-time and a non-employed mother (although in the latter case we can only look at crossover from fathers' working conditions to mothers' WFBS). None of these alternative specifications changed the results for instrumental social support, which was still not significant in any of the paths (available upon request). However, some interesting differences in the mediating role of emotional support emerged: In couples with two full-time working parents, only the crossover relationship 
between mothers' unsupportive work-family culture and their partner's WFBS was transmitted by emotional support. In couples with a father working full-time and a mother working part-time, only fathers' emotional support was related to their partner's WFBS, but the indirect effect is only significant at the $10 \%$ level. In couples with a father working full-time and a non-employed mother, the crossover relationship between fathers' workplace culture and their partner's WFBS was significantly transmitted by emotional support. The results thus indicate that emotional support as a mechanism in the crossover process differs by parents' division of paid work.

In a second set of models, we tested alternative specifications of our indicator of instrumental social support. We tested a) hours spent on childcare and housework as separate mediators; b) whether the relationship between hours spent in unpaid work and WFBS is u-shaped rather than linear; c) whether there is a direct crossover from an unsupportive work-family culture at one parent's workplace to the other parent's hours spent on childcare and housework; d) satisfaction with the division of unpaid work between partners; and e) actual weekly working times as a potential precondition to the time available for childcare and housework. None of these alternative models revealed evidence that instrumental social support mediates the relationship between an unsupportive work-family culture at one partner's workplace and the other partner's WFBS. In sum, the robustness checks further reinforced the findings above.

Taken together, our regression analyses showed that there is only a robust direct crossover connection between fathers' perceptions of an unsupportive work-family culture and mothers' WFBS, whereas fathers' WFBS was not robustly related to their partners' workplace situation. Dyadic mediation analyses revealed that emotional social support acted as a mediator in this crossover relationship for both mothers and fathers. The more parents' perceived an unsupportive work-family culture in their workplace, the more likely they were to report work-related conflicts with their partner and, in turn, the less satisfied their partner felt about the overall work-family balance in the household.

\section{Discussion}

This study aimed to shed light on whether and how workplace demands in the form of an unsupportive work-family culture can cross over from one partner to the other and reduce the latter's satisfaction with work-family balance. To this end, we integrated the literatures on work-family balance satisfaction, workplace culture, and crossover into one theoretical framework.

Our analyses based on couple data from Germany suggest that workplace conditions are of greater relevance for families than has been established in previous research as they also matter for employees' partners. We found robust evidence that mothers are less satisfied with the overall work-family balance in their household if their partner reported an unsupportive work-family culture in his workplace. The results are robust to a wide range of the couples' individual and family characteristics that might impact both their selection into certain work cultures and their work-family balance satisfaction (see Perry-Jenkins and Gerstel 2020 for an overview). Our results thus lend support to arguments made in previous studies that family members' lives are intertwined and that partners are mutually affected by each other's well-being (Westman 2001; Bakker et al. 2009; Brough et al. 2018). 
At the same time, we found only weak evidence for crossover of an unsupportive work-family culture in mothers' workplaces to fathers' satisfaction with work-family balance. This finding is in line with the argument that female and male partners may be unequally affected by each other's well-being (Moen 2001; Craig and Brown 2017). Valcour (2007) argued that demanding working conditions are likely to be more detrimental to mothers' than fathers' work-family balance satisfaction because mothers tend to feel and assume more responsibility for meeting family needs than fathers. Our regression analyses corroborate and extend this idea, showing that this holds not only for the individual's own but also the partner's working conditions: Compared to fathers, mothers' satisfaction depends more strongly on cultural norms at both their own and their partner's workplace. In other words, mothers are more likely to feel that family life is compromised if either parent's workplace culture demands that employees prioritize work over all outside concerns. Another argument that has been put forward as an explanation for stronger crossover from fathers' workplace conditions to mothers' well-being is that mothers often resolve tensions between work and family by switching to part-time work (Lewis 2001; OECD 2017).

Our study also empirically tested whether emotional and instrumental social support are potential mechanisms explaining the interrelation between one parent's experience of an unsupportive work-family culture and the other parent's satisfaction with workfamily balance. The results only partially confirm previous arguments in the literature.

Our dyadic mediation analyses suggested that the crossover associations are transmitted partly by reduced emotional support. Hence, our findings lend support to the argument that an unsupportive work-family culture in one parent's workplace may deplete their resources to such an extent that they not only are less capable of providing emotional support to their partner but also need more emotional support from their partner, both of which deplete their partner's resources (Westman 2001). As a consequence, the less empathetic interaction style tends to increase relationship conflicts and to reduce the partner's work-family balance satisfaction (Abendroth and den Dulk 2011). Yet whereas emotional social support mediated the relationship between mothers' workplace culture and fathers' satisfaction to a great extent, it explained only a small part of the relationship between fathers' workplace culture and mothers' satisfaction. Moreover, the role of emotional support in the crossover process differed by couples' employment arrangement. In couples with two full-time working parents, fathers' work-family balance satisfaction appeared to be more strongly related to their female partner's working conditions via emotional support than vice versa. Conversely, in couples with a male breadwinner, only mothers' satisfaction was compromised by their partner's working conditions through lack of emotional support. These findings are in line with arguments that couples actually fail to resolve tensions between work and family by opting for unequal work-care arrangements, since mothers who mostly choose to work part-time or work not at all still suffer from their partner's work situation (OECD 2017).

Contrary to our expectations, instrumental support did not play a role in the crossover between one partner's unsupportive work-family culture and the other partner's workfamily balance satisfaction. Given the study's focus on dual-earner couples with young children, who face extensive care demands, this finding surprised us. Previous studies (Demerouti et al. 2005; ten Brummelhuis et al. 2010) argued that one partner's work demands increase the other partner's family load, which, in turn, reduces the satisfaction of the latter. To our knowledge this assumption had not previously been tested 
empirically, although Bakker et al. (2008) found that one partner's work-family conflict was positively related to the other partner's home demands (a factor composed of both overload and emotional demands). Our analyses and extensive robustness tests did not yield any evidence for such a crossover process. On average, both partners' time spent in childcare and housework was positively correlated, which runs counter to the expectation that one partner compensates for the other's inability to spend more time in unpaid work. This result confirms findings based on German time use data, which show that couples tend to synchronize their involvement in care work (Walper and Lien 2018).

Taken together, our findings for emotional and instrumental social support as mechanisms in the crossover process suggest that psychological well-being may be more important for explaining the crossover process than the actual division of labor (Nomaguchi et al. 2005; see Abendroth and den Dulk 2011). This may indicate that even in the context of demanding working conditions, dual-earner couples are still capable of managing family demands in terms of time, but that they do so at the cost of their relationship quality and ultimately of both partners' satisfaction with the overall work-family balance. It is noteworthy that instrumental support did not even explain why parents themselves feel less satisfied if they experience an unsupportive work-family culture in their workplace (spillover).

\section{Implications for Actors in Workplace Organizations}

Our main finding that high-demand work cultures are associated with increased relationship conflicts and thereby impair both partners' work-family balance satisfaction has practical implications for organizational leaders, employee representatives and workers. Organizational leaders that strive for a healthy and committed workforce need to become aware of the long arm of a family-unsupportive work culture in organizations. Work cultures that are structured around expectations of an "ideal worker" unencumbered by family responsibilites appear very persistent and hard to change. Promising approaches have suggested three main elements of developing a "sustainable workforce strategy": redesigning work processes to accommodate workers' caregiving needs, providing workers with social support and offering equal career opportunities (Kossek et al. 2014b; Kossek and Ollier-Malaterre 2020). Work (re-)design is based on participative management methods in which supervisors guide their teams in dialogue processes that initiate change in cultural norms and facilitate new ways of working that allow employees more autonomy in managing work and family roles according to their needs (Perlow and Kelly 2014). To be successful, this change in workplace culture should be initiated and supported both by top management (top down) and employee representatives such as equal opportunities counsellors and work councils (bottom up), and be accompanied by trainings for organizational leaders and administration on work-family supportive management (Kossek et al. 2014a).

\section{Limitations and Future Research}

Our contribution has some limitations that may have implications for the interpretation of the results and for future research. One caveat is that our item for emotional support is unidimensional and measures the absence of social support by increased levels of relationship conflict due to high work demands. Although previous research provides evidence that 
relationship conflicts can be equated with low levels of emotional support (Abbey et al. 1985), it is also possible that high workplace demands result in relationship withdrawal (Repetti 1989). This aspect of low emotional support was not captured by our measure. According to a study by Schulz et al. (2004), women were more likely to show angry marital behavior in response to high workplace demands whereas men tended to be more withdrawn. This may explain the gender differences we found with regard to emotional social support. Regarding instrumental support, our measures of hours spent on childcare and housework on a normal workday do not capture "cognitive labor" (Daminger 2019), which is difficult to measure, but may be an important aspect of instrumental social support. It should also be kept in mind that, as our data are only cross-sectional, the results do not allow us to draw any conclusions about whether partners react to changes in their own and each other's workplace culture by changing the amount of time they both spend in unpaid household and care work. To examine these questions, it might be fruitful to advance the measurement of work-family balance satisfaction at the couple level. In this study, we used a single-item global measure of satisfaction with the overall work-family balance in the household to capture mutual dependence in balance assessments as proposed in our theoretical crossover framework. Complementing this global appraisal by measures of subdimensions could strengthen construct validity (Casper et al. 2018). In addition, it may inform balance theory in whether instrumental and emotional social support are more relevant for some aspects of work-family balance satisfaction than for others, e.g. instrumental social support may be particularly related to satisfaction with the allocation of time to work and family tasks between partners, whereas emotional support may be more relevant to satisfaction with the allocation of attention (see also Valcour 2007).

Furthermore, we need more knowledge whether these findings from the German context can be generalized to other countries. First, given that the culture of long working hours is not so widespread in Germany, and many mothers work part-time, an unsupportive work-family culture may be even more detrimental to families in other countries such as the US. Second, even though we did not find much heterogeneity in work-family balance satisfaction related to ethnicity, occupational position or firm characteristics, the findings of this study are largely limited to white middle-class families. Further research is therefore needed to scrutinize the relations between workplace demands, social support, and families' well-being in different cultural and social contexts. This study provides a useful framework for analyzing the processes of how demands - and potentially also resources - within work organizations affect not only individuals but entire families.

Acknowledgements We thank Till Kaiser for advice on implementing SEM in Stata and Oliver ArránzBecker for his helpful comments on the mediation analysis.

Authors' Contributions Both authors contributed to all parts of the manuscript.

Funding Open Access funding enabled and organized by Projekt DEAL. We acknowledge funding from the Hans Böckler Foundation (Grant 2015-926-3).

Data Availability Data are available at https://doi.org/10.7802/2039.

Code Availability The authors used Stata 15.1. Code is available upon request. 


\section{Declarations}

Conflicts of Interest/Competing Interests The authors declare that they have no conflict of interest. This work has not been published before and is not under consideration for publication anywhere else. Its publication has been approved by all co-authors.

\section{Appendix 1}

Table 4 Regression Models of Work-Family Balance Satisfaction: Crossover of Partners' Experience of an Unsupportive Work-Family Culture in Their Workplaces

Work-Family Balance Satisfaction

Mothers Fathers

(1)

(2)

(3)

(4)

\begin{tabular}{|c|c|c|c|c|c|c|c|c|}
\hline $\begin{array}{l}\text { Unsupportive work-family culture at own work- } \\
\text { place }\end{array}$ & $-0.21^{* * * *}$ & $(0.03)$ & $-0.21^{* * * *}$ & $(0.03)$ & $-0.16^{* * * *}$ & $(0.03)$ & $-0.16^{* * *}$ & $(0.03)$ \\
\hline $\begin{array}{l}\text { Unsupportive work-family culture at partner's } \\
\text { workplace }\end{array}$ & $-0.07^{*}$ & $(0.03)$ & $-0.08^{*}$ & $(0.03)$ & -0.03 & $(0.03)$ & -0.05 & $(0.03)$ \\
\hline \multicolumn{9}{|l|}{ Own characteristics } \\
\hline \multicolumn{9}{|l|}{ Sector (ref: administration, healthcare, social services) } \\
\hline Production & & & $0.67^{*}$ & $(0.30)$ & & & 0.15 & $(0.22)$ \\
\hline Retail, hospitality & & & 0.27 & $(0.27)$ & & & -0.27 & $(0.34)$ \\
\hline Scientific services & & & $0.43^{*}$ & $(0.21)$ & & & -0.33 & $(0.26)$ \\
\hline Other sectors & & & 0.16 & $(0.23)$ & & & 0.09 & $(0.22)$ \\
\hline \multicolumn{9}{|l|}{ Establishment size (ref: medium) } \\
\hline Small & & & -0.48 & $(0.25)$ & & & -0.11 & $(0.25)$ \\
\hline Large & & & 0.06 & $(0.16)$ & & & 0.17 & $(0.15)$ \\
\hline \multicolumn{9}{|l|}{ Occupational position (ref: white collar) } \\
\hline Blue collar & & & -0.04 & $(0.35)$ & & & -0.02 & $(0.26)$ \\
\hline Civil servant & & & $0.49^{*}$ & $(0.24)$ & & & 0.26 & $(0.22)$ \\
\hline Management position & & & 0.27 & $(0.17)$ & & & 0.13 & $(0.14)$ \\
\hline Education: Tertiary degree & & & -0.03 & $(0.19)$ & & & -0.16 & $(0.17)$ \\
\hline Age & & & -0.03 & $(0.02)$ & & & 0.01 & $(0.02)$ \\
\hline Egalitarian gender role attitudes & & & 0.02 & $(0.14)$ & & & -0.10 & $(0.15)$ \\
\hline Handles stress well & & & $0.15^{\text {***** }}$ & $(0.04)$ & & & 0.06 & $(0.04)$ \\
\hline \multicolumn{9}{|l|}{ Partners' characteristics } \\
\hline \multicolumn{9}{|l|}{ Sector (ref: administration, healthcare, social services) } \\
\hline Production & & & -0.08 & $(0.23)$ & & & -0.06 & $(0.26)$ \\
\hline Retail, hospitality & & & -0.28 & $(0.35)$ & & & -0.05 & $(0.28)$ \\
\hline Scientific services & & & $-0.56^{*}$ & $(0.28)$ & & & -0.46 & $(0.29)$ \\
\hline Other sector & & & -0.27 & $(0.23)$ & & & 0.18 & $(0.19)$ \\
\hline \multicolumn{9}{|l|}{ Establishment size (ref: medium) } \\
\hline Small & & & 0.44 & $(0.32)$ & & & -0.34 & $(0.21)$ \\
\hline Large & & & 0.08 & $(0.15)$ & & & 0.26 & $(0.16)$ \\
\hline
\end{tabular}


Table 4 (continued)

Work-Family Balance Satisfaction

Mothers Fathers

(1)

(2)

(3)

(4)

\begin{tabular}{|c|c|c|c|c|c|c|c|c|}
\hline \multicolumn{9}{|l|}{ Occupational position (ref: white-collar) } \\
\hline Blue-collar & & & -0.09 & $(0.30)$ & & & -0.11 & $(0.36)$ \\
\hline Civil servant & & & -0.09 & $(0.24)$ & & & $0.41^{*}$ & $(0.20)$ \\
\hline Management position & & & -0.14 & $(0.15)$ & & & 0.25 & $(0.18)$ \\
\hline University degree & & & -0.03 & $(0.19)$ & & & -0.14 & $(0.18)$ \\
\hline Age & & & $0.04^{*}$ & $(0.02)$ & & & -0.00 & $(0.02)$ \\
\hline Egalitarian gender role attitudes & & & -0.19 & $(0.17)$ & & & 0.18 & $(0.14)$ \\
\hline Handles stress well & & & -0.00 & $(0.04)$ & & & -0.03 & $(0.03)$ \\
\hline \multicolumn{9}{|l|}{ Couples' characteristics } \\
\hline Region: Eastern Germany & & & 0.04 & $(0.17)$ & & & 0.10 & $(0.17)$ \\
\hline Marital status: Married & & & -0.21 & $(0.26)$ & & & 0.23 & $(0.30)$ \\
\hline Age of youngest child: under 3 years old & & & 0.05 & $(0.23)$ & & & 0.20 & $(0.24)$ \\
\hline Number of children: three or more & & & -0.13 & $(0.17)$ & & & -0.09 & $(0.16)$ \\
\hline \multicolumn{9}{|c|}{ Employment arrangement (ref: father working full-time, mother working part-time) } \\
\hline Both working full-time & -0.04 & $(0.16)$ & -0.28 & $(0.18)$ & 0.04 & $(0.16)$ & -0.02 & $(0.17)$ \\
\hline Both working part-time & -0.08 & $(0.26)$ & -0.26 & $(0.28)$ & $0.56^{*}$ & $(0.22)$ & $0.57^{*}$ & $(0.24)$ \\
\hline Other & -0.05 & $(0.38)$ & -0.33 & $(0.36)$ & 0.01 & $(0.38)$ & 0.13 & $(0.41)$ \\
\hline Constant & $7.09^{* * * *}$ & $(0.10)$ & $6.10^{* * * *}$ & $(0.87)$ & $7.05^{* * * *}$ & $(0.09)$ & $6.10^{* * * *}$ & $(0.75)$ \\
\hline Observations & 556 & & 556 & & 556 & & 556 & \\
\hline
\end{tabular}

Note: Unstandardized coefficients, bootstrap standard errors in parentheses $(2000$ replications); $* \mathrm{p}<0.05$, ** $\mathrm{p}<0.01$, *** $\mathrm{p}<0.001$; unweighted data; sample: dual-earner couples

Open Access This article is licensed under a Creative Commons Attribution 4.0 International License, which permits use, sharing, adaptation, distribution and reproduction in any medium or format, as long as you give appropriate credit to the original author(s) and the source, provide a link to the Creative Commons licence, and indicate if changes were made. The images or other third party material in this article are included in the article's Creative Commons licence, unless indicated otherwise in a credit line to the material. If material is not included in the article's Creative Commons licence and your intended use is not permitted by statutory regulation or exceeds the permitted use, you will need to obtain permission directly from the copyright holder. To view a copy of this licence, visit http://creativecommons.org/licenses/by/4.0/.

\section{References}

Abbey, A., Abramis, D. J., \& Caplan, R. D. (1985). Effects of different sources of social support and social conflict on emotional well-being. Basic and Applied Social Psychology, 6(2), 111-129. https://doi.org/10. 1207/s15324834basp0602_2.

Abendroth, A.-K., \& den Dulk, L. (2011). Support for the work-life balance in Europe: The impact of state, workplace and family support on work-life balance satisfaction. Work, Employment and Society, 25(2), 234-256. https://doi.org/10.1177/0950017011398892. 
Abendroth, A.-K., \& Reimann, M. (2018). Telework and work-family conflict across workplaces: Investigating the implications of work-family-supportive and high-demand workplace cultures. In S. L. Blair \& J. Obradović (Eds.), The work-family interface: Spillover, complications, and challenges (Vol. 13, pp. 323-348, contemporary perspectives in family research). Bingley: Emerald Publishing Limited.

Acker, J. (1990). Hierarchies, jobs, bodies: A theory of gendered organizations. Gender \& Society, 4(2), 139158. https://doi.org/10.1177/089124390004002002.

Acock, A. C. (2013). Discovering structural equation modeling using Stata (a Stata press publication). College Station: StataCorp LP.

Allard, K., Haas, L., \& Hwang, C. P. (2011). Family-supportive organizational culture and fathers' experiences of work-family conflict in Sweden. Gender, Work and Organization, 18(2), 141-157. https://doi.org/10. 1111/j.1468-0432.2010.00540.x.

Allen, T. D. (2001). Family-supportive work environments: The role of organizational perceptions. Journal of Vocational Behavior, 58(3), 414-435. https://doi.org/10.1006/jvbe.2000.1774.

Amstad, F. T., Meier, L. L., Fasel, U., Elfering, A., \& Semmer, N. K. (2011). A meta-analysis of work-family conflict and various outcomes with a special emphasis on cross-domain versus matching-domain relations. Journal of Occupational Health Psychology, 16(2), 151-169. https://doi.org/10.1037/ a0022170.

Bakker, A. B., Demerouti, E., \& Dollard, M. F. (2008). How job demands affect partners' experience of exhaustion: Integrating work-family conflict and crossover theory. Journal of Applied Psychology, 93(4), 901-911. https://doi.org/10.1037/0021-9010.93.4.901.

Bakker, A. B., Westman, M., \& van Emmerik, I. J. H. (2009). Advancements in crossover theory. Journal of Managerial Psychology, 24(3), 206-219. https://doi.org/10.1108/02683940910939304.

Barnett, M. D., Martin, K. J., \& Garza, C. J. (2019). Satisfaction with work-family balance mediates the relationship between workplace social support and depression among hospice nurses. Journal of Nursing Scholarship, 51(2), 187-194. https://doi.org/10.1111/jnu.12451.

Beham, B., \& Drobnič, S. (2010). Satisfaction with work-family balance among German office workers. Journal of Managerial Psychology, 25(6), 669-689. https://doi.org/10.1108/02683941011056987.

Bernhardt, J., \& Bünning, M. (2020). Fathers' working times in Germany: What role do cultural and structural workplace conditions play? In M. L. H. Maestro, N. C. Albiol, \& M. G. Grau (Eds.), The New Ideal Worker: Organizations between work-life balance, gender and leadership (pp. 25-48, contributions to management science). Cham: Springer international publishing.

Blair-Loy, M. (2003). Competing devotions: Career and family among women executives. Cambridge, Mass: Harvard Univ. Press.

Bond, S. (2004). Organisational culture and work-life conflict in the UK. International Journal of Sociology and Social Policy, 24(12), 1-24. https://doi.org/10.1108/01443330410790795.

Booth, S. M., \& Matthews, R. A. (2012). Family-supportive organization perceptions: Validation of an abbreviated measure and theory extension. Journal of Occupational Health Psychology, 17(1), 41-51. https://doi.org/10.1037/a0026232.

Booth-LeDoux, S. M., Matthews, R. A., \& Wayne, J. H. (2020). Testing a resource-based spillover-crossoverspillover model: Transmission of social support in dual-earner couples. The Journal of Applied Psychology, 105(7), 732-747. https://doi.org/10.1037/ap10000460.

Brough, P., Muller, W., \& Westman, M. (2018). Work, stress, and relationships: The crossover process model. Australian Journal of Psychology, 70(4), 341-349. https://doi.org/10.1111/ajpy.12208.

Cameron, A. C., \& Trivedi, P. K. (2005). Microeconometrics: Methods and applications. Cambridge: Cambridge University Press.

Carlson, D. S., \& Perrewé, P. L. (1999). The role of social support in the stressor-strain relationship: An examination of work-family conflict. Journal of Management, 25(4), 513-540. https://doi.org/10.1177/ 014920639902500403.

Carlson, D. S., Grzywacz, J. G., \& Zivnuska, S. (2009). Is work-family balance more than conflict and enrichment? Human Relations, 62(10), 1459-1486. https://doi.org/10.1177/0018726709336500.

Casper, W. J., Vaziri, H., Wayne, J. H., DeHauw, S., \& Greenhaus, J. (2018). The jingle-jangle of worknonwork balance: A comprehensive and meta-analytic review of its meaning and measurement. The Journal of Applied Psychology, 103(2), 182-214. https://doi.org/10.1037/apl0000259.

Cha, Y. (2010). Reinforcing separate spheres: The effect of spousal overwork on men's and women's employment in dual-earner households. American Sociological Review, 75(2), 303-329. https://doi.org/ $10.1177 / 0003122410365307$.

Clark, S. C. (2001). Work cultures and work/family balance. Journal of Vocational Behavior, 58(3), 348-365. https://doi.org/10.1006/jvbe.2000.1759. 
Clark, M. A., Rudolph, C. W., Zhdanova, L., Michel, J. S., \& Baltes, B. B. (2017). Organizational support factors and work-family outcomes: Exploring gender differences. Journal of Family Issues, 38(11), 1520-1545. https://doi.org/10.1177/0192513X15585809.

Cozzolino, E., Prickett, K. C., \& Crosnoe, R. (2018). Relationship conflict, work conditions, and the health of mothers with young children. Journal of Family Issues, 39(12), 3177-3202. https://doi.org/10.1177/ $0192513 X 18776415$.

Craig, L., \& Brown, J. E. (2017). Feeling rushed: Gendered time quality, work hours, nonstandard work schedules, and spousal crossover. Journal of Marriage and Family, 79(1), 225-242. https://doi.org/10. 1111/jomf.12320.

Crouter, A. C., Bumpus, M. F., Head, M. R., \& McHale, S. M. (2001). Implications of overwork and overload for the quality of men's family relationships. Journal of Marriage and Family, 63(2), 404 416. https://doi. org/10.1111/j.1741-3737.2001.00404.x.

Daminger, A. (2019). The cognitive dimension of household labor. American Sociological Review, 84(4), 609-633. https://doi.org/10.1177/0003122419859007.

Demerouti, E., Bakker, A. B., \& Schaufeli, W. B. (2005). Spillover and crossover of exhaustion and life satisfaction among dual-earner parents. Journal of Vocational Behavior, 67(2), 266-289. https://doi.org/ 10.1016/j.jvb.2004.07.001.

den Dulk, L., Bäck-Wiklund, M., Lewis, S., \& Redai, D. (2011). Quality of life and work in a changing Europe: A Theoretical Framework. In M. Bäck-Wiklund, T. van der Lippe, L. den Dulk, \& A. DoorneHuiskes (Eds.), Quality of life and work in Europe: Theory, practice and policy (pp. 17-31). New York: Palgrave Macmillan.

Elder, G. H. (1994). Time, human agency, and social change: Perspectives on the life course. Social Psychology Quarterly, 57(1), 4-15. https://doi.org/10.2307/2786971.

Epstein, C. F., Seron, C., Oglensky, B., \& Saute, R. (1999). The part-time paradox: Time norms, professional lives, family, and gender. New York: Routledge.

Frone, M. R. (2003). Work-family balance: Chapter 7. In J. C. Quick (Ed.), Handbook of occupational health psychology (pp. 143-162). Washington: American Psychological Assoc.

Fuller, S., \& Hirsh, C. E. (2019). "Family-friendly" jobs and motherhood pay penalties: The impact of flexible work arrangements across the educational spectrum. Work and Occupations, 46(1), 3-44. https://doi.org/ $10.1177 / 0730888418771116$.

Goñi-Legaz, S., \& Ollo-López, A. (2016). The impact of family-friendly practices on work-family balance in Spain. Applied Research in Quality of Life, 11(3), 983-1007. https://doi.org/10.1007/s11482-015-9417-8.

Greenhaus, J. H., \& Allen, T. D. (2011). Work-family balance: A review and extension of the literature. In J. C. Quick \& L. E. Tetrick (Eds.), Handbook of occupational health psychology (2nd ed., pp. 165-183). Washington: American Psychological Association.

Greenhaus, J. H., \& Beutell, N. J. (1985). Sources of conflict between work and family roles. Academy of Management Review, 10(1), 76-88. https://doi.org/10.5465/AMR.1985.4277352.

Greenhaus, J. H., \& Powell, G. (2006). When work and family are allies: A theory of work-family enrichment. Academy of Management Review, 31(1), 72-92. https://doi.org/10.5465/AMR.2006.19379625.

Greenhaus, J. H., Collins, K. M., \& Shaw, J. D. (2003). The relation between work-family balance and quality of life. Journal of Vocational Behavior, 63(3), 510-531. https://doi.org/10.1016/S0001-8791(02)00042-8.

Grunow, D., Begall, K., \& Buchler, S. (2018). Gender ideologies in Europe: A multidimensional framework. Journal of Marriage and the Family, 80(1), 42-60.

Grzywacz, J. G., \& Carlson, D. S. (2007). Conceptualizing work-family balance: Implications for practice and research. Advances in Developing Human Resources, 9(4), 455-471. https://doi.org/10.1177/ 1523422307305487.

Hayes, A. F. (2013). Introduction to mediation, moderation, and conditional process analysis: A regressionbased approach (Methodology in the social sciences). New York: Guilford Press.

Hays, S. (1996). The cultural contradictions of motherhood. New Haven and London: Yale University Press.

House, J. S. (1981). Work stress and social support (Addison-Wesley series on occupational stress, Vol. 4). Reading, Mass: Addison-Wesley.

Junker, N. M., \& van Dick, R. (2020). Congruence in preferences and expectations of work-family role management: Operationalization and the relation with work-family balance and spousal support. Sex Roles, 82(11-12), 644-658. https://doi.org/10.1007/s11199-019-01085-1.

Kossek, E. E., \& Ollier-Malaterre, A. (2020). Desperately seeking sustainable careers: Redesigning professional jobs for the collaborative crafting of reduced-load work. Journal of Vocational Behavior, 117, 103315. https://doi.org/10.1016/j.jvb.2019.06.003. 
Kossek, E. E., Noe, R. A., \& DeMarr, B. J. (1999). Work-family role synthesis: Individual and organizational determinants. International Journal of Conflict Management, 10(2), 102-129. https://doi.org/10.1108/ eb022820.

Kossek, E. E., Hammer, L. B., Kelly, E. L., \& Moen, P. (2014a). Designing work, family \& health organizational change initiatives. Organizational Dynamics, 43(1), 53-63. https://doi.org/10.1016/j. orgdyn.2013.10.007.

Kossek, E. E., Valcour, M., \& Lirio, P. (2014b). The sustainable workforce: Organizational strategies for promoting work-life balance and wellbeing. In P. Y. Chen, C. Cooper, \& L. (Eds.), Wellbeing: A complete reference guide: Volume III. Work and wellbeing (pp. 295-318). Wiley-Blackwell: Chichester.

Kumar, A., Channa, K. A., \& Bhutto, N. A. (2019). When and how workplace social support improves family performance. Applied Research in Quality of Life, 14(5), 1183-1204. https://doi.org/10.1007/s11482-0189647-7.

Lareau, A. (2003). Unequal childhoods: Class, race, and family life. Berkeley: University of California Press.

Las Heras Maestro, M., Chinchilla Albiol, N., \& Grau Grau, M. (Eds.). (2020). The New Ideal Worker: Organizations between work-life balance, gender and leadership (contributions to management science). Cham: Springer International Publishing.

Leslie, L. M., Manchester, C. F., Park, T.-Y., \& Mehng, S. A. (2012). Flexible work practices: A source of career premiums or penalties? Academy of Management Journal, 55(6), 1407-1428. https://doi.org/10. 5465/amj.2010.0651.

Lewis, S. (1997). 'Family friendly' employment policies: A route to changing organizational culture or playing about at the margins? Gender. Work \& Organization, 4(1), 13-23. https://doi.org/10.1111/ 1468-0432.00020.

Lewis, J. (2001). The decline of the male breadwinner model: Implications for work and care. Social Politics, $8(2), 152-169$. https://doi.org/10.1093/sp/8.2.152.

Lott, Y., \& Klenner, C. (2018). Are the ideal worker and ideal parent norms about to change? The acceptance of part-time and parental leave at German workplaces. Community, Work \& Family, 21(5), 564-580. https://doi.org/10.1080/13668803.2018.1526775.

Matias, M., Ferreira, T., Vieira, J., Cadima, J., Leal, T., \& Mena Matos, P. (2017). Workplace family support, parental satisfaction, and work-family conflict: Individual and crossover effects among dual-earner couples. Applied Psychology, 66(4), 628-652. https://doi.org/10.1111/apps.12103.

Mennino, S. F., Rubin, B. A., \& Brayfield, A. (2005). Home-to-job and job-to home spillover: The impact of company policies and workplace culture. The Sociological Quarterly, 46(1), 107-135. https://doi.org/10. 1111/j.1533-8525.2005.00006.x.

Michel, J. S., Mitchelson, J. K., Pichler, S., \& Cullen, K. L. (2010). Clarifying relationships among work and family social support, stressors, and work-family conflict. Journal of Vocational Behavior, 76(1), 91104. https://doi.org/10.1016/j.jvb.2009.05.007.

Milkie, M. A., Kendig, S. M., Nomaguchi, K. M., \& Denny, K. E. (2010). Time with children, children's wellbeing, and work-family balance among employed parents. Journal of Marriage and Family, 72(5), 13291343. https://doi.org/10.1111/j.1741-3737.2010.00768.x.

Moazami-Goodarzi, A., Nurmi, J.-E., Mauno, S., Aunola, K., \& Rantanen, J. (2019). Longitudinal latent profiles of work-family balance: Examination of antecedents and outcomes. International Journal of Stress Management, 26(1), 65-77. https://doi.org/10.1037/str0000093.

Moen, P. (2001). The gendered life course. In R. H. Binstock \& L. K. George (Eds.), Handbook of aging and the social sciences (pp. 179-196). San Diego: Academic Press.

Moen, P. (2003). Linked lives: Dual careers, gender, and the contingent life course. In W. R. Heinz \& V. W. Marshall (Eds.), Social dynamics of the life course: Transitions, institutions, and interrelations (pp. 237257). New York: Aldine de Gruyter.

Nomaguchi, K., \& Milkie, M. A. (2020). Parenthood and well-being: A decade in review. Journal of Marriage and Family, 82(1), 198-223. https://doi.org/10.1111/jomf.12646.

Nomaguchi, K. M., Milkie, M. A., \& Bianchi, S. M. (2005). Time strains and psychological well-being. Journal of Family Issues, 26(6), 756-792. https://doi.org/10.1177/0192513X05277524.

OECD. (2017). Dare to share: Germany's experience promoting equal partnership in families. Paris: OECD.

OECD. (2019). OECD Family Database. http://www.oecd.org/els/family/database.htm. Accessed 8 February 2021.

Perlow, L. A., \& Kelly, E. L. (2014). Toward a model of work redesign for better work and better life. Work and Occupations, 41(1), 111-134. https://doi.org/10.1177/0730888413516473.

Perry-Jenkins, M., \& Gerstel, N. (2020). Work and family in the second decade of the 21 st century. Journal of Marriage and Family, 82(1), 420-453. https://doi.org/10.1111/jomf.12636. 
Preacher, K. J., \& Hayes, A. F. (2008). Asymptotic and resampling strategies for assessing and comparing indirect effects in multiple mediator models. Behavior Research Methods, 40(3), 879-891. https://doi.org/ 10.3758/BRM.40.3.879.

Rammstedt, B., \& John, O. P. (2007). Measuring personality in one minute or less: A 10-item short version of the big five inventory in English and German. Journal of Research in Personality, 41(1), 203-212. https://doi.org/10.1016/j.jrp.2006.02.001.

Repetti, R. L. (1989). Effects of daily workload on subsequent behavior during marital interaction: The roles of social withdrawal and spouse support. Journal of Personality and Social Psychology, 57(4), 651-659. https://doi.org/10.1037//0022-3514.57.4.651.

Sallee, M. W. (2012). The ideal worker or the ideal father: Organizational structures and culture in the gendered university. Research in Higher Education, 53(7), 782-802. https://doi.org/10.1007/s11162-0129256-5.

Schnettler, B., Miranda-Zapata, E., Grunert, K. G., Lobos, G., Lapo, M., \& Hueche, C. (2020). Testing the spillover-crossover model between work-life balance and satisfaction in different domains of fife in dualearner households. Applied Research in Quality of Life, Advance online publication. https://doi.org/10. 1007/s11482-020-09828-z.

Schulz, M. S., Cowan, P. A., Cowan, C. P., \& Brennan, R. T. (2004). Coming home upset: Gender, marital satisfaction, and the daily spillover of workday experience into couple interactions. Journal of Family Psychology, 18(1), 250-263. https://doi.org/10.1037/0893-3200.18.1.250.

Szücs, S., Drobnič, S., den Dulk, L., \& Verwiebe, R. (2011). Quality of life and satisfaction with the work-life balance. In M. Bäck-Wiklund, T. van der Lippe, L. den Dulk, \& A. Doorne-Huiskes (Eds.), Quality of life and work in Europe: Theory, practice and policy (pp. 95-117). New York: Palgrave Macmillan. https:// doi.org/10.1057/9780230299443_6

ten Brummelhuis, L. L., Haar, J. M., \& van der Lippe, T. (2010). Crossover of distress due to work and family demands in dual-earner couples: A dyadic analysis. Work \& Stress, 24(4), 324-341. https://doi.org/10. 1080/02678373.2010.533553.

UCLA: Statistical Consulting Group (n.d.). How can I analyze multiple mediators in Stata? UCLA: Statistical Consulting Group. https://stats.idre.ucla.edu/stata/faq/how-can-i-analyze-multiple-mediators-in-stata/. Accessed 8 February 2021.

Valcour, M. (2007). Work-based resources as moderators of the relationship between work hours and satisfaction with work-family balance. Journal of Applied Psychology, 92(6), 1512-1523. https://doi. org/10.1037/0021-9010.92.6.1512.

van der Lippe, T., \& Lippényi, Z. (2020). Beyond formal access: Organizational context, working from home, and work-family conflict of men and women in European workplaces. Social Indicators Research, 151(2), 383-402. https://doi.org/10.1007/s11205-018-1993-1.

Vieira, J. M., Matias, M., Lopez, F. G., \& Matos, P. M. (2018). Work-family conflict and enrichment: An exploration of dyadic typologies of work-family balance. Journal of Vocational Behavior, 109, 152-165. https://doi.org/10.1016/j.jvb.2018.10.007.

Vinkenburg, C. J., van Engen, M. L., Coffeng, J., \& Dikkers, J. S. E. (2012). Bias in employment decisions about mothers and fathers: The (dis)advantages of sharing care responsibilities. Journal of Social Issues, 68(4), 725-741. https://doi.org/10.1111/j.1540-4560.2012.01773.x.

Voydanoff, P. (2004). The effects of work demands and resources on work-to-family conflict and facilitation. Journal of Marriage and Family, 66(2), 398-412. https://doi.org/10.1111/j.1741-3737.2004.00028.x.

Voydanoff, P. (2005a). Toward a conceptualization of perceived work-family fit and balance: A demands and resources approach. Journal of Marriage and Family, 67(4), 822-836. https://doi.org/10.1111/j.17413737.2005.00178.x.

Voydanoff, P. (2005b). Work demands and work-to-family and family-to-work conflict. Journal of Family Issues, 26(6), 707-726. https://doi.org/10.1177/0192513X05277516.

Walper, S., \& Lien, S. (2018). Routinebetreuung und interaktive "Quality Time": Was beeinflusst, wieviel Zeit Väter wie mit ihren Kindern verbringen? Zeitschrift für Familienforschung, 30(1), 29-49. https://doi. org/10.3224/zff.v30i1.03.

Wayne, J. H., Butts, M. M., Casper, W. J., \& Allen, T. D. (2017). In search of balance: A conceptual and empirical integration of multiple meanings of work-family balance. Personnel Psychology, 70(1), 167210. https://doi.org/10.1111/peps.12132.

Westman, M. (2001). Stress and strain crossover. Human Relations, 54(6), 717-751. https://doi.org/10.1177/ 0018726701546002.

Westman, M., \& Etzion, D. (2005). The crossover of work-family conflict: From one spouse to the other. Journal of Applied Social Psychology, 35(9), 1936-1957. https://doi.org/10.1111/j.1559-1816.2005. tb02203.x. 
Williams, J. C. (2000). Unbending gender: Why family and work conflict and what to do about it. Oxford: Oxford University Press.

Williams, J. C., Blair-Loy, M., \& Berdahl, J. L. (2013). Cultural schemas, social class, and the flexibility stigma. Journal of Social Issues, 69(2), 209-234. https://doi.org/10.1111/josi.12012.

Yucel, D. (2020). Different types of work-family balance, social support, and job satisfaction: A latent class analysis. Applied Research in Quality of Life, Advance online publication. https://doi.org/10.1007/ s11482-020-09812-7.

Publisher's Note Springer Nature remains neutral with regard to jurisdictional claims in published maps and institutional affiliations.

\section{Affiliations}

\section{Janine Bernhardt ${ }^{1} \cdot$ Mareike Bünning $^{2}$}

1 German Youth Institute (DJI), Munich, Germany

2 WZB Berlin Social Science Center, Berlin, Germany 